\title{
VYUŽITÍ VÝSLEDKŮ ANALÝZ NUMERICKÝCH MODELƯ PĚŠí DOPRAVY PRO PLÁNOVÁNÍ VEŘEJNÝCH PROSTORŮ
}

\author{
USE OF THE RESULTS OF ANALYSIS OF NUMERICAL MODELS OF \\ PEDESTRIAN TRANSPORT FOR URBAN PUBLIC SPACE PLANNING
}

\author{
Daniel Nikolov",, Petra Okřinová ${ }^{1}$
} ${ }^{*}$ Daniel.Nikolov@vutbr.cz
${ }^{1}$ Vysoké učení technické v Brně, Fakulta stavební, Ústav technologie, mechanizace a řízení staveb, Veveři 331/95, 60200 Brno, Česká
republika

\begin{abstract}
Abstrakt
Simulace se v jakémkoliv kontextu stávají naprostým standardem již v mnoha oborech. A právě numerické modely pěší dopravy mohou být účinným nástrojem i ve stavebnictví. Sloužit mohou především odborníkům z řad urbanistů, architektů, projektových inženýrů, úředníků stavebních odborů obcí a měst při rozhodování o nejlepším řešení návrhu veřejných ploch. Optimalizace numerickým modelováním poskytuje potřebnou zpětnou vazbu a možnosti opakovaného ověřování návrhu pro nalezení inovativního řešení ze strany tvưrců. Za pomoci jejich výstupů lze identifikovat kritická místa a plochy, které z pohledu pěší dopravy nevyhovují komfortním kritériím.
\end{abstract}

\section{Klíčová slova}

Pathfinder, analýza dopravního uzlu, Mendlovo náměstí, Brno, numerické modelování, pěší doprava

\begin{abstract}
Simulation, in any context, is already becoming the absolute standard in many fields. And numerical models of pedestrian traffic can also be an effective tool in the construction sector. They can mainly serve experts from urban planners, architects, project engineers, municipal and urban building department in choosing the best solution for public areas design. Optimization by numerical modelling provides the necessary feedback and possibilities for repeated design verification to find innovative solutions by creators. Using their outputs, it is possible to identify critical points and areas that do not meet the comfort criteria of pedestrian traffic.
\end{abstract}

Key words

Pathfinder, traffic hub analysis, Mendel's Square, Brno, numerical modelling, pedestrians transport

\section{1 ÚVOD}

V současnosti se numerické modelování pěší dopravy zabývá převážně evakuacemi ohrožených osob vzniklým nebezpečím anebo posuzováním evakuačních norem. Nově také můžeme přijít do styku s modelováním běžného provozu pěší dopravy na náměstích, zastávkách, přestupních uzlech, očkovacích centrech, podchodech apod. Výsledky simulací těchto modelů mohou pomoci ověřit současný stav nebo připravovaný návrh vzhledem k šířce profilů a jejich celkových kapacit, rychlostí, komfortu a trajektorií jednotlivých osob. Práce má sloužit jako nástroj k rozpoutání diskuse z řad odborníků, kteří pro svou práci používají převážně normy, všeobecné zásady navrhování a vlastní zkušenosti. Vytvořením numerického modelu pěši dopravy je možné posoudit kvalitu pěší dopravy a hodnotu tvorby numerických modelů běžných provozů. Cílem práce je poskytnout optimalizaci, která povede ke zlepšení komfortu $\mathrm{v}$ tomto řešeném území. Zde se práce zaměřuje především na návrh geometrie prostoru, rozmístění mobiliáře a jeho vliv na samotné proudění osob v prostoru dopravního uzlu na Mendlově náměstí v Brně. Tento článek navazuje na předešlou autorovu práci, vybrané obrázky a textové pasáže jsou čerpané z [1] a [2]. 


\section{POPIS SOUČASNÉHO STAVU}

Aktuálně se v zahraničí setkáváme se dvěma typy analýz kvality a komfortu chodců. Jedna se zabývá povětrnostními vlivy (přehřiváním měst, prouděním vzduchu atd.) a jeho účinky na pocity chodce [3], [4]. Druhá zkoumá základní a vztažené veličiny pěší dopravy jako dynamického pohybu [5], [6]. Tato práce se zabývá vlivem umístění městského mobiliáře a celkové geometrie objektů na kvalitu pěší dopravy v rámci dopravního uzlu. Další, $\mathrm{s}$ čím přicházíme do styku jsou průvodci navrhování pěších komunikací čerpající právě z analýz numerických modelů pěší dopravy. Jeden takový má i londýnská metropole z roku 2010 [7]. České poměry jsou v tomto ohledu více konzervativní a spoléhají na starší a tradičnější způsoby analýzy pěší dopravy: směrový průzkum, ruční sčítání osob a obsazenosti veřejné dopravy. Tento způsob sběru a analýzy dat není zcela přesný právě při velkých intenzitách pěší dopravy, se kterými se setkáváme na místech typu dopravní uzel. Jako první řešení se nabízí spojení funkcí Smart City (dále jen SC) s numerickým modelováním pěší dopravy. V tomto směru již probíhají pilotní projekty pro sběr dat kamerovými systémy za pomocí strojového vidění [8], [9] anebo pomocí pasivních infračervených senzorů připojených do sítě IoT [10].

Dalším aspektem bezpečnosti veřejných prostor je aktuálně hojně využíván termín „ochrana měkkých cílů“, který se používá pro místa s velkým soustředěním osob a nízkou úrovní zabezpečení. Pro analýzu rizik v těchto př́padech jsou využívány numerické modely i v České republice, např. evakuace metra, evakuace Arény Brno či odbavovací haly v Praze [11], [12], [13], [14]. Souhrnně se bavíme o tzv. behaviorálních jevech. Tyto davové jevy jsou v zahraniční literatuře podrobně popsány a blíže zkoumány [15], [16], [17], [18], [19], [20], [21].

\section{METODIKA}

Pro tvorbu numerického modelu je využito softwarového nástroje Pathfinder [22]. Jedná se o mikroskopický model využívající agentní technologie s behaviorálními aspekty a spojitou sítí. Do modelu jsou následně zaneseny data o geometrii území, počtu osob a jejich pohybu. Model byl vytvořen ve třech variantách, ale $\mathrm{v}$ rámci tohoto př́spěvku jsou ukázány pouze určité úseky této práce.

Základní informace jsou čerpány z certifikované metodiky CERO [22] a směrnice RIMEA [23], vědeckých publikací [25], [26]. Informace o osobách vyskytujících se v modelu jsou získány z dat zpracovaných Českým statistickým úrradem [27] a geolokačních analýz [28]. Další parametry chodců jako je jejich rychlost jsou brány z publikací [26], [29]. Data o vytíženosti dopravního uzlu byla sledována in situ v časech ranní špičky 7:30-8:30. Při tvorbě modelů byla přijata následující zjednodušení:

- Geometrie (jedna výšková úroveň, pevně určená místa pro přecházení vozovky);

- Rozdělení a zastoupení osob (muži <30-50+ let, ženy <30-50+ let a postižení [27], [23]);

- Profil agenta (rozměry, rychlosti a diskrétní zóna chodců jsou distribuovány funkcí $L N$ );

- Vzorce chování (3 hlavní vzorce chování, složených ze 143 samostatných vzorců chování);

- Modelování nástupu a výstupu z veřejné dopravy pomocí místností a směrových dveří viz Obr. 1.

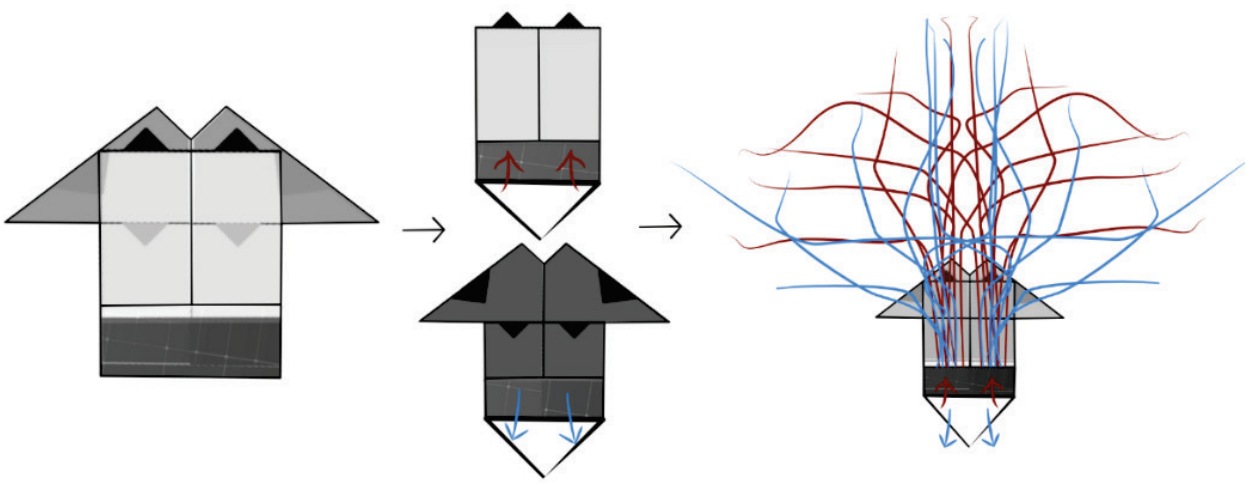

Obr. 1 Princip modelování výstupu (červená) a nástupu (modrá) agentů do veřejné dopravy [1].

Základními veličinami pro posuzování kvality pěší dopravy jsou hustota $\mathrm{os} \cdot \mathrm{m}^{-2}$, rychlost $\mathrm{m} \cdot \mathrm{s}^{-1}$ a intenzita osoba $\cdot \mathrm{s}^{-1}$. Pro účely měřitelnosti ukazatelů byla definována elipsa těla jako uzavřená křivka, která představuje $95 \%$ percentil půdorysného tvaru dospělého muže s minimální diskrétní zónou $(2 \mathrm{a}= \pm 610 \mathrm{~mm} ; 2 \mathrm{~b}= \pm 460 \mathrm{~mm})$. 
Další definice elipsy těla je založena na základě jeho ergonomie. Plocha tělesného prostoru se pohybuje mezi hodnotami $0,20-0,26 \mathrm{~m}^{2}$, čemuž odpovídá hodnota maximální statické hustoty $4-5 \mathrm{os} \cdot \mathrm{m}^{-2}$. Při porušení dynamické rovnováhy se osoba z klidového stavu dostává do dynamického pohybu, ten se vyznačuje vektorovou rychlostí $0,5-1,5 \mathrm{~m} \cdot \mathrm{s}^{-1}$ (ø po rovině), intenzitou a maximální dynamickou hustotou $2-3 \mathrm{os} \cdot \mathrm{m}^{-2}$. Posuzování kvality pěší dopravy probíhá především pomocí kvalitativní stupnice LoS - Level of Service [22], [25], [26].

\section{APLIKAČNÍ PŘÍKLAD A JEHO VÝSLEDKY}

\section{Popis aplikačního příkladu}

Předmětem zkoumání je případová studie dopravního uzlu Mendlovo náměstí. V rámci modelu jsou zaneseny provozní schéma, stávající a navrhované geometrie. Celkově jsou vytvořeny 3 modely dopravního uzlu Mendlova náměstí - stávající, revitalizovaný (vítězný návrh soutěže pořádané Kanceláři architekta města, dále jen KAM) a optimalizovaný stav, který byl navržen autory po vyhodnocení předešlých variant). Modely jsou vytvořeny pro čas 7:30-8:30 s jednotnou délkou simulovaného času 3600 s. Vstupní obsazenost je modelována pro jednotlivé intenzity na vstupních koridorech řešeného dopravního uzlu, s počátečním náhodným rozptýlením 500 osob. Modelované varianty se především liší uspořádáním navrhované geometrie, od které se odvíjí jednotlivé pozice služeb, zastávek a celkový pohyb osob.

\section{Vybrané výsledky aplikačního př́íkladu}

Na základě získaných výsledků (např. trajektorií, průměrné rychlosti, hustoty osob, intenzity, kvalita pěší dopravy atd.) jsme schopni provést efektivní analýzu veřejného prostoru a jeho provozních celků a samotného komfortu pohybu osob v tomto prostoru. Při analýze identifikujeme kritická místa, místa s nevyhovující kapacitou, špatné návaznosti provozu apod díky čemuž jsem schopni uspořádat prostor lépe, tak aby bylo docíleno plynulého a komfortního pohybu. V následující části bude demonstrováno užití numerického modelu pro optimalizaci prostoru na vybraných výsledcích.

\section{Trajektorie osob}

Pomocí analýzy trajektorií jsme schopni detekovat samotné směrování osob jejich pohyb po prostoru a celkové zatížení jednotlivých částech analyzovaného prostoru, jak je názorně vidět na Obr. 2.

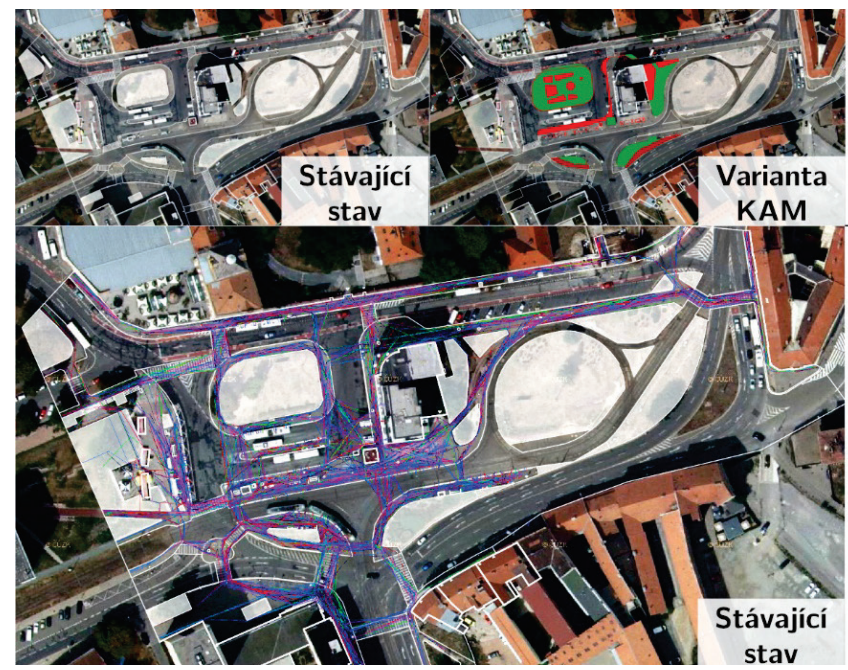

Legenda:

$\square$ Stávajíci geometrie

$\square$ Bourané plochy a kce

$\square$ Nové plochy a kce

$\begin{array}{rrrr}1 & 1 & 1 & 100 \\ 0 & 50 & m\end{array}$

Legenda:

$\square$ Stávajíci geometrie

Trajektorie chodců

Obr. 2 Mapové podklady a ukázka výsledných trajektoriích proudění osob v prostoru dopravního uzlu [1]. 


\section{LoS - Level of Service}

Dále při analýze je využito hodnocení kvality pěší dopravy Level of Service (dále už jen LoS), jejichž škálou hodnotíme uživatelský komfort posuzovaného prostoru v závislosti na typu - koridory, schodiště a rozptylové plochy, které v aplikačním př́kladu zkoumáme.

Na Obr. 3 jsou uvedeny př́klady hodnocení LoS s cílem porovnání stávající navrhované a nově optimalizované varianty řešení daného prostoru. Z výsledků je patrný vliv geometrie a umístění městského mobiliáře na komfort chodců. Při optimalizaci první scény viz Obr. 3 (vlevo) dochází k natočení zastávky a posunutí automatu na jízdenky, čímž došlo ke zvětšení rozptylových ploch a odstranění úzkého koridoru. Na druhé scéně Obr. 3 (vpravo) je představeno ověření efektivnosti navrhovaných úprav úplného odstranění stánku s novinami a vzniku nového zákazu parkování, díky čemuž dle výsledné heat mapy došlo k výraznému zvýšení vytíženosti posuzovaného prostoru, a tedy i k zatraktivnění těchto ploch pro jeho uživatele.

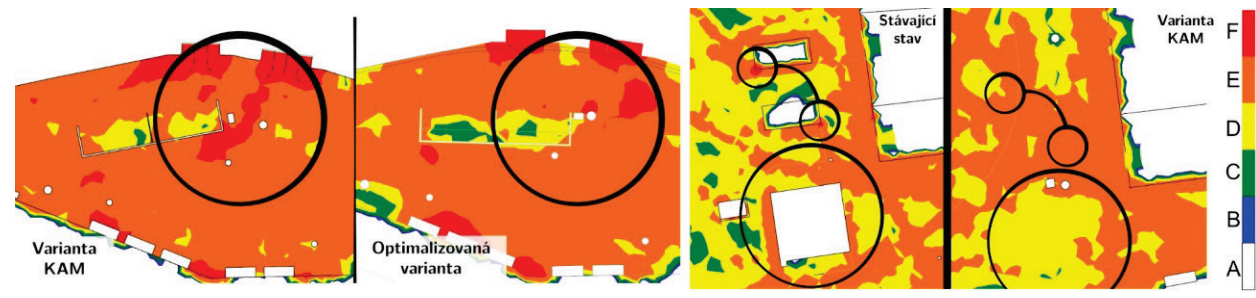

Obr. 3 Ukázka ověření vlivu optimalizace řešených části řešeného dopravního uzlu - posouzení maximálně dosažených hodnot LoS - prostor tramvajové zastávky (vlevo) a prostor nároží domu (vpravo) [1].

\section{Hustota}

Poslední vybranou veličinou užitou v rámci analýzy je hustota osob na metr čtvereční, kterou lze detekovat místa v provozu s potencionální možností vzniku kritické události a kolizí osob.

Na Obr. 4 (vlevo) je vyobrazen prostor mezi stánky, kde je umístěn i nově navrhovaný mobiliár̆, který dle vyhodnocení výsledků je umístěný prímo v přirozených trajektoriích cestujících dopravního uzlu. V optimalizované variantě došlo $\mathrm{k}$ jeho odstranění a výsledky ukazují úspěšné rozptýlení vysokých hustot a také zlepšení propustnosti v místě přirozeného koridoru. Další podobný problém je vyobrazen na Obr. 4 (vpravo), kde je na první pohled nevhodné umístění laviček na spojnici mezi dvěma přestupními body. Po ověření optimalizované varianty bylo zjištěno, že umístění laviček je naprosto odůvodněné a nijak nemění poměr kvality pěší dopravy v tomto koridoru.
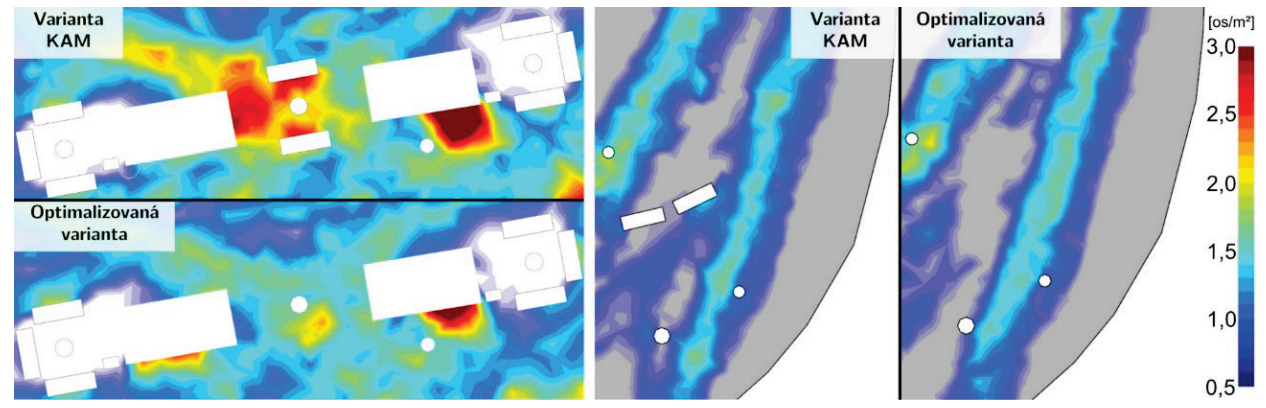

Obr. 4 Ukázka výsledků posouzení maximální dosažené hustoty - v prostoru mezi stánky (vlevo) a jejího vlivu při umístění laviček do koridoru (vpravo) [1]. 


\section{DISKUZE}

Využití numerického modelování pro analyzování pěší dopravy je velice efektivní a nabízí širokou škálu možností. Díky provedeným analýzám a jejím vyhodnocením se docílilo úspěšné optimalizace. Odstraněním kritických míst a překážek z veřejného prostoru došlo ke zvýšení komfortu a snížení kongescí, což lze považovat za velmi pozitivní výsledek práce.

Největším přínosem numerického modelu je právě upozornění na kritická místa, nebo také ověření správnosti navrhovaných řešení, jako je tomu u výsledků na Obr. 3 kdy po rozpoznání kritického místa na nástupišti byla v optimalizované variantě zastřešená zastávka pouze natočena. Touto úpravou došlo k výraznému zlepšení kvality pěší dopravy z pohledu LoS. Dalším výsledkem, který svědčí o přínosech numerického modelu je na Obr. 4, kde se umístění laviček vyskytuje v přirozených trajektoriích chodců. Ověřením se oddělil mobiliáŕ, který má dopad na kvalitu pěší dopravy (prŕípad vlevo) a na mobiliář, který na kvalitu vliv nemá (př́ípad vpravo).

\section{ZÁVĚR}

Vyžití numerického modelování pro analyzování pěší dopravy lze pokládat za velmi účinný nástroj pro plánování a ověřování budoucí výstavby. Výsledky pomáhají nalézt odpovědi na otázky ohledně základních veličin pro posuzování kvality a komfortu pěší dopravy (jako jsou např. plynulost proudění, celkové zdržení), ale třeba i při tvorbě časových harmonogramů (jízdních řádů, časových intervalů pro semafory) a v poslední řadě také při organizaci a optimalizaci velkých provozů (letiště, očkovací centra, dopravní uzly apod). Možnost ověření návrhu a následné detekce jeho kritických míst před samotnou realizací pomáhá při zvyšování komfortu pohybu chodců a snižování vzniku kongescí. Celkově je tento nástroj prevence budoucích vícenákladů na odstraňování provozních chyb návrhu, které nemusely být na první pohled zřejmé. Výsledky tedy mohou sloužit především městským architektům jako podklad pro plánování, ale také jako funkční nastroj pro ověřování finálních řešení.

\section{Poděkování}

Př́spěvek vznikl za podpory interního projektu Vysokého učení technického v Brně s registračním číslem FAST-J-21-7528.

\section{Použité zdroje}

[1] Bc. Daniel Nikolov Analýza dopravního uzlu s využitím simulačních nástrojů. Brno, 2021. 93 s.. Diplomová práce. Vysoké učení technické v Brně, Fakulta stavební, Ústav automatizace inženýrských úloh a informatiky. Vedoucí práce Ing. Petra Okřinová.

[2] OKŘINOVÁ, Petra a Daniel NIKOLOV. Využití numerických modelů a moderních technologií pro návrh a optimalizaci veřejného prostoru města. In: KUGL, Jiří. Sborník abstraktů 15: Člověk stavba územní plánování. 15. Praha: Fakulta stavební ČVUT v Praze, 2021, s. 22-33. ISBN 9788001069110. ISSN 9788001069110.

[3] S. Mballo, S. Herpin, M. Manteau, S. Demotes-Mainard, P.E. Bournet, Impact of well-watered trees on the microclimate inside a canyon street scale model in outdoor environment, Urban Climate, Volume 37, 2021, 100844, ISSN 2212-0955, https://doi.org/10.1016/j.uclim.2021.100844.

[4] Taihan Chen, Haonan Pan, Mengrong Lu, Jian Hang, Cho Kwong Charlie Lam, Chao Yuan, David Pearlmutter, Effects of tree plantings and aspect ratios on pedestrian visual and thermal comfort using scaled outdoor experiments, Science of The Total Environment, Volume 801, 2021, 149527, ISSN 0048-9697, https://doi.org/10.1016/j.scitotenv.2021.149527.

[5] Dezhen Zhang, Gaoyue Huang, Chengtao Ji, Huiying Liu, Ying Tang, Pedestrian evacuation modeling and simulation in multi-exit scenarios, Physica A: Statistical Mechanics and its Applications, Volume 582, 2021, 126272, ISSN 0378-4371, https://doi.org/10.1016/j.physa.2021.126272.

[6] Meng Shi, Eric Wai Ming Lee, Yi Ma, Wei Xie, Ruifeng Cao, The density-speed correlated mesoscopic model for the study of pedestrian flow, Safety Science, Volume 133, 2021, 105019, ISSN 0925-7535, https://doi.org/10.1016/j.ssci.2020.105019.

[7] Pedestrian Comfort Level Guidance First Edition 2010 Version 2 (2019), [Online]: http://content.tfl.gov.uk/pedestrian-comfort-guidance-technical-guide.pdf.

[8] Peter Kok-Yiu Wong, Han Luo, Mingzhu Wang, Pak Him Leung, Jack C.P. Cheng, Recognition of pedestrian trajectories and attributes with computer vision and deep learning techniques, Advanced Engineering Informatics, Volume 49, 2021, 101356, ISSN 1474-0346, 
https://doi.org/10.1016/j.aei.2021.101356.

[9] (C) 2021 RCE systems s.r.o., Data From Sky, [Online]: https://datafromsky.com/flow/

[10] AKHTER F, Khadivizand. IoT Enabled Intelligent Sensor Node for Smart City: Pedestrian Counting and Ambient Monitoring. Sensors (Basel), 2019. Dostupné z: doi:10.3390/s19153374

[11] OKŘINOVÁ, Petra, Tomáš APELTAUER a Petr BENEŠ. Model evakuace tunelu metra I.D. In: Sborník abstraktů při 19. odborné konference doktorského studia, Juniorstav 2017. Brno: Vysoké učení technické v Brně, 2017, s. 1-14. ISBN 978-80-214-5473-6.

[12] APELTAUER, Tomáš, Jiří APELTAUER, Petra OKŘINOVÁ, Ondřej UHLÍK a Martin PAŘIL. Závěrečná zpráva - Aréna Brno: Simulace evakuace osob z objektu Multifunkčního sportovního a kulturního pavilonu. Vysoké učení technické v Brně, Fakulta stavební, Ústav automatizace inženýrských úloh a informatiky, 2020.

[13] OKŘINOVÁ, Petra a Tomáš APELTAUER. Analýza pěší dopravy u náhradního uzlu Brno-Dolní nádraží. Silniční obzor. Brno-Starý Lískovec: Nakladatelství Silniční společnosti, 1922, 2018, (79), 272-275. ISSN 0322-7154.

[14] OKŘINOVÁ, P.; APELTAUER, T.; BENEŠ, P. Užití numerických modelů v dopravním systému pražského metra D. In Sborník příspěvků - JUNIORSTAV 2018. Brno: Vysoké učení technické v Brně, 2018. s. 1-10. ISBN: 978-80-86433-69-1.

[15] DONG, H, M ZHOU, Q WANG a AJ. State-of-the-Art Pedestrian and Evacuation Dynamics. 2019. Transactions on Intelligent Transportation.

[16] JIANG, Y.-Q., S.-G. ZHOU a F.-B. TIAN. A higher-order macroscopic model for bidirection pedestrian ow. Physica A: Statistical Mechanics and its Applications. 425. 2015, s. $69\{78$.

[17] MURAMATSU, M a T NAGATANI. Jamming transition in two-dimensional pedestrian tra_c. Physica A: Statistical Mechanics and its Applications. Roč. 275. 2000, s. $281\{291.1-2$.

[18] YUEN, J. a E. LEE. The e_ect of overtaking behavior on unidirectional pedestrian ow. Safety Science. Roč. 50. 2012, s. $1704\{1714$. e. 50.

[19] HELBING, D a P MUKERII. Crowd disasters as systemic failures: analysis of the Love Parade disaster: EPJ Data Science. 1. 2012, str. 7. e. 1.

[20] GANIEH, M a B. EINOLLAHI. Mass fatalities in Hajj in 2015: Trauma monthly. 2016. e. 5, ročník 21.

[21] Pedestrian Comfort Level Guidance First Edition 2010 Version 2 (2019) - New link to spreadsheet added.

[22] Pathfinder Technical Reference [online]. 403 Poyntz Avenue, Suite B, Manhattan, KS 66502, USA: Thunderhead Engeneering, 2020 [cit. 2021-11-16]. Dostupné z: https:/www.thunderheadeng.com/wp-content/uploads/dlm_uploads/2011/07/tech_ref-6.pdf

[23] RIMEA: Richtlinie für Mikroskopische Entfluchtungsnalysen. 3.0.0. Wien: RiMEA, 2016.

[24] APELTAUER, Tomáš, Petr BENEŠ a Luděk VRÁNA. Aplikace pokročilých modelů pohybu osob a dynamiky požáru pro bezpečnou evakuaci osob a analýzu rizik: VG20132015120 Bezpečná hromadná evakuace osob s využitím pokročilých simulací davové dynamiky a požáru [online]. Brno: Vysoké učení technické v Brně, Fakulta stavební., 2015. Certifikovaná metodika. Vysoké uèení technické v Brnì, Fakulta stavební.

[25] PHEASANT, S. Bodyspace: Anthropometry. Ergonomics and the Design of the Work. CRC Press, 1996.

[26] STILL, G. Introduction to Crowd Science. CRC Press, 2014.

[27] ČSÚ [Český statistický úřad]. Výsledky sčítání lidu, domů a bytů 2011 (SLDB 2011) [online]. [vid. 2021-07-15]. Dostupné z: https://www.czso.cz/csu/czso/otevrena_data_pro_vysledky_scitani_ lidu_domu_a_bytu_2011_sldb_2011

[28] ODDĚLENÍ DAT, analýz. Data.brno. C Statutární město Brno, 2020. Dostupné také z: https://data.brno.cz

[29] Weidmann, U.: Transporttechnik der Fußgänger. Technická zpráva, Institut für Verkehrsplanung, Transporttechnik, Strassen- und Eisenbahnbau, 1993. 